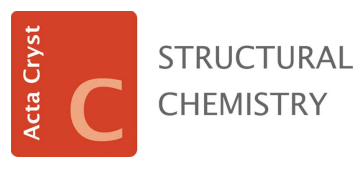

ISSN 2053-2296

\title{
There's many a good tune played on an old fiddle - a new colour for Alfred Werner's isomer counting
}

\author{
Edwin C. Constable* \\ University of Basel, Department of Chemistry, BPR 1096, Mattenstrasse 24a, CH-4058 Basel, Switzerland. \\ *Correspondence e-mail: edwin.constable@unibas.ch
}

Keywords: Alfred Werner; coordination chemistry; cobalt complex; ethane-1,2-diamine; octahedral.

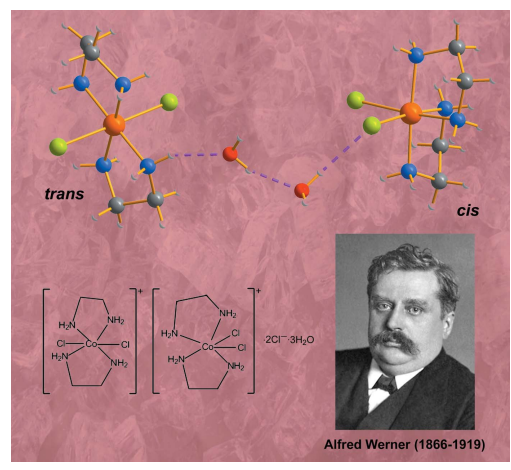

Chemical history often teaches that Alfred Werner (1866-1919) was the 'Founder of Coordination Chemistry' (Kauffman, 1966). In the sense that he was responsible for the modern vision of coordination chemistry and the clear distinction between oxidation number, Hauptvalenz, and coordination number, Nebenvalenz (Constable \& Housecroft, 2013; Werner, 1893, 1911, 1920), this accolade is justified. However, as Bernal \& Lalancette (2020) state in their publication in Acta Crystallographica Section C: Structural Chemistry, the reality is a little more complex.

Although Werner and his co-workers in Zürich were prolific experimentalists, most of these studies were performed after the publication of his seminal work of 1893 (Werner, 1893). In writing his Beitrag zur Konstitution anorganischer Verbindungen, Werner drew extensively on the large body of experimental work published by other chemists. Bernal \& Lalancette (2020) particularly identify the compounds prepared by Sophus Mads Jørgensen (Kauffman, 1959) and Otto Linné Erdmann as being key elements in the development of his coordination model. This is not the place to revamp the controversy between Werner and Jørgensen, which is adequately documented elsewhere (Kauffman, 1960; Constable, 2019), although the interpretation is currently subject to some degree of revisionism (Kragh, 1997). It is certainly true that a vast number of the compounds used by Werner in developing his model were first prepared or characterized by Jørgensen or Erdmann, but this is also not the entire story.

The coordination chemistry of cobalt started at the end of the $18^{\text {th }}$ Century CE with the description of what subsequently proved to be $\left[\mathrm{Co}\left(\mathrm{NH}_{3}\right)_{6}\right]^{3+}$ by Tassaert (1798). This led to an exponential expansion of interest in cobalt chemistry in the following half century or so. Although the contributions of Jørgensen or Erdmann are exceptional, the contributions of Leoppold Gmelin, Emil Dingler, Karl Georg Winkelblech (Karl Marlo), Wilhelm von Beetz, Georg Vortmann, Frederic Just Claudet, Edmond Fremy and Karl Friedrich August Rammelsberg and many others are of equal importance (Constable, 2019). Among the unsung heroes of $19^{\text {th }}$ Century coordination chemistry are Friedrich August Ludwig Karl Wilhelm Genth and Oliver Wolcott Gibbs who described a vast number of cobalt compounds in a series of publications in the 1850s and 1870s (Kauffman, 1977; Genth, 1851; Gibbs, 1873, 1875a,b; Gibbs \& Genth, 1857a,b,c). They were also responsible for the popularization of the names for coordination compounds based on prefixes such as luteo-, croceo- and purpureo-, based on the colour of the prototype cobalt(III) complexes.

One of Werner's arguments for the octahedral coordination of complexes such as those of cobalt(III) relied on the number of isomers that could be isolated. Compounds of the type $\left[\mathrm{Co} A_{4} X_{2}\right]^{+}\left(A_{4}=\right.$ four amine $\mathrm{N}$-atom donors and $X=$ halido ligand $)$ were a critical

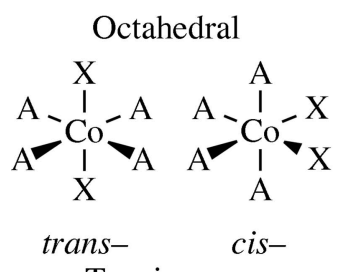

Two isomers
Hexagonal planar

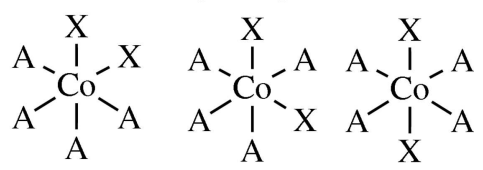

Three isomers 
part of the establishment of the octahedral coordination geometry as opposed to a hexagonal planar one. Only two isomers, cis- $\left[\mathrm{Co} A_{4} X_{2}\right]^{+}$and trans- $\left[\mathrm{Co} A_{4} X_{2}\right]^{+}$, were to be expected for octahedral complexes, whereas three would be found for a hexagonal planar one (Fig. 1). First described by Jörgensen (1889), the isolation of only two forms of $\left[\mathrm{CoCl}_{2}\right.$ (en $\left.)_{2}\right] \mathrm{Cl}$, viz. violet cis-[ $\left.\mathrm{CoCl}_{2}(\mathrm{en})_{2}\right] \mathrm{Cl}$ and green trans$\left[\mathrm{CoCl}_{2}(\mathrm{en})_{2}\right] \mathrm{Cl}$, was one of the observations used to support the proposed octahedral geometry. The argument was that in no case had more than two isomers been found for $\left[\mathrm{Co} A_{4} X_{2}\right]^{+}$ complexes, although this is not an unambiguous establishment of the geometry, in particular because it relied on the nonobservation of a third isomer.

Now, 131 years after the original publication by Jörgensen, the crystal structure of a new form of $\left[\mathrm{CoCl}_{2}(\mathrm{en})_{2}\right] \mathrm{Cl}$ is reported by Bernal \& Lalancette (2020). This compound is a purple form that contains equal amounts of the cis-[ $\mathrm{CoCl}_{2}-$ (en $\left.)_{2}\right] \mathrm{Cl}$ and trans- $\left[\mathrm{CoCl}_{2}(\mathrm{en})_{2}\right] \mathrm{Cl}$ isomers. It is really quite remarkable that this purple form has not been noted before, considering that the preparation of the cis- $\left[\mathrm{CoCl}_{2}(\mathrm{en})_{2}\right] \mathrm{Cl}$ and trans-[ $\left.\mathrm{CoCl}_{2}(\mathrm{en})_{2}\right] \mathrm{Cl}$ isomers is incorporated in so many undergraduate practical courses at universities around the world. The authors speculate what might have happened if Werner had been aware of, or if his co-workers had isolated, this form. It would probably not have demolished the case for the octahedral geometry, as this was built on evidence from more compounds than $\left[\mathrm{CoCl}_{2}(\mathrm{en})_{2}\right] \mathrm{Cl}$ alone. Nevertheless, it would likely have caused him some sleepless nights!

This report is both interesting and important as it allows us to reassess the early work of Werner and brings an emphasis to the occurrence of cocrystals of complexes. Although the phenomenon of cocrystallization is well-established and investigated for organic compounds and pharmaceuticals, it is less well-documented or recognized in coordination chemistry. A search in Scifinder (https://www.cas.org/products/scifinder) for the terms 'cocrystal' and 'cobalt' combined yielded 234 hits, suggesting that there is a rich area for data-mining here.

\section{References}

Bernal, I. \& Lalancette, R. A. (2020). Acta Cryst. C76, 298-301.

Constable, E. C. (2019). Chemistry, 1, 126-163.

Constable, E. C. \& Housecroft, C. E. (2013). Chem. Soc. Rev. 42, 1429-1439.

Genth, F. A. (1851). Keller-Tiedem's Nordamerikanischer Monatsbericht für Natur- und Heilkunde, 2, 8-12.

Gibbs, W. (1873). Am. J. Sci., Ser. 3, Vol. 6, pp. 116-125.

Gibbs, W. (1875a). Proc. Am. Acad. Arts Sci. 10, 1-38.

Gibbs, W. (1875b). Proc. Am. Acad. Arts Sci. 11, 1-51.

Gibbs, W. \& Genth, F. A. (1857a). Am. J. Sci. 23, 234-265.

Gibbs, W. \& Genth, F. A. (1857b). Am. J. Sci. 23, 319-341.

Gibbs, W. \& Genth, F. A. (1857c). Am. J. Sci. 24, 86-107.

Jörgensen, S. M. (1889). J. Prakt. Chem. 39, 1-26.

Kauffman, G. B. (1959). J. Chem. Educ. 36, 521-527.

Kauffman, G. B. (1960). Chymia, 6, 180-204.

Kauffman, G. B. (1966). In Father of Coordination Chemistry. Berlin, Heidelberg: Springer-Verlag.

Kauffman, G. B. (1977). Isis, 68, 392-403.

Kragh, H. (1997). Br. J. Hist. Sci. 30, 203-219.

Tassaert, B. M. (1798). Ann. Chim. Phys. 28, 92-107.

Werner, A. (1893). Z. Anorg. Chem. 3, 267-330.

Werner, A. (1911). In New Ideas on Inorganic Chemistry. Translated, with the author's sanction, from the second German edition. New York, Bombay, Calcutta: Longmans, Green and Co.

Werner, A. (1920). In Neuere Anschaunngen auf dem Gebiete der anorganischen Chemie, 4th ed. Braunschweig: Friedrich Vieweg \& Sohn. 